\title{
The Effect of the Microsoft Excel based Interactive Learning Media on the Physics Problem Solving
}

\author{
Irnin Agustina Dwi Astuti ${ }^{1}$ and Yoga Budi Bhakti ${ }^{2}$ \\ 1,2 Indraprasta PGRI, Indonesia \\ Jl. Raya Tengah No.80, Gedong, Pasar Rebo, Jakarta Timur \\ Email: irnin.agustina@gmail.com
}

\begin{abstract}
The physics problem solving is needed students to overcome the phenomenon of physics. The development of technology in physics learning is able to explain the concept of abstract physics. This study aims to know effect of use interactive learning media based Microsoft Excel on the physics problem solving. The subject on this media is Heat and Temperature. The research method used is pretest-postest controlled group design. The analysis technique is used t-test with SPSS 16.0 with a margin of error of 5\%. The results of this study showed that the mean scores of post-test treatment class students significantly better than the average score post-test control class indicated by the average score of students' post-test treatment class at 80.26 and scores the average post-test control class at 68.00 and with SPSS analyze sig value is 0.000 . While the average score gain results-physics students learn physics class treatment significantly better than the average score gain results Physics students learn physics-control class indicated by the average score of physics problem solving gain of 0.77 and the treatment class the average score gain control class student physics problem solving of 0.63 .
\end{abstract}

Keywords: physics problem solving, interactive learning media, Microsoft Excel, physics learning.

\section{Introduction}

Physics learning is the combination of learning activities in the form of abstract theories to be connected in a real life. Learning activities will be very fun and have meaning if the teacher is right in choose the method, model or media. Mistakes in choosing a method or media in the learning of physics will have an impact on less interesting learning process so that the students' learning motivation is low, which will have a low impact on student learning outcomes. Inadequate student learning outcomes are caused by low problem-solving abilities.

Problem solving is a basic activity for humans because in human life will definitely deal with the problem. Science can also be interpreted as a way of thinking in solving a problem [I]. However, in-class learning tends to emphasize mastery of concepts and override students' physics problem solving abilities [2]. Students experience difficulties when faced with complex problems. Students are able to solve simple quantitative problems but lack the ability to solve more complex problems [3]. In fact, one of the goals of physics learning is to create human beings who can solve complex problems by applying their knowledge and understanding to everyday situations [4].

Learning media could support learners' problemsolving and critical-thinking abilities. The use of learning media in a form of e-learning could improve learning into becoming more efficient with support from the learning motivation possessed by learners and it has a sufficiently significant impact on the e-learning [5]. Learning with technological media exerts a sufficiently significant influence with learners getting a stimulation effect from the use of the media in the learning process [6].

The aims of physics learning is to develop problemsolving abilities by applying concepts to the calculation appropriately. To improve the ability of physics problem solving, it needs to develop interactive learning media that can explain the concept and also the calculation. The learning media to be developed is Microsoft Excel. It can be used as a media delivery concept like a powerpoint slide. The advantage of this media is the students can understand concepts as well as mathematical calculations together. 
From the result of the development of learning media based Microsoft Excel by Astuti [7], shows that the media worth tested to students with the average feasibility 3.4. Media has not been tested to students, it is necessary to conduct large-scale trials to determine the effectiveness of learning media on the learning of physics at school.

\section{Literature Review}

\section{Learning Media}

Information and Communication Technology (ICT) in learning makes learners feel more sure and more directly involved in the learning activity and, in addition, ICT-based learning activity should also be supported with teacher ability in using ICT in daily learning practice [8]. Learning media is a tool in teaching and learning process, can be printed media, voice media, audio-video media, interactive media, and e-learning. Learning Media can add the attractiveness of the material, so it can increase the motivation and the proclivity. Then it can take the student's attention to focus on following the material presented, so it also expected the learning effectively will be increased $[9,10]$.

\section{Microsoft Excel}

Microsoft Excel is usually used to analyze values in school activities. This program is often used by accountants to write or record expenses and income in the company or an institution or small agencies. Microsoft Excel program is very useful in chemistry teaching due to its extensive ability in processing and presenting data [7, II]. Microsoft Excel is very important to analyse physics experiment, such as physics simulation, linear regression, VBA (Visual Basic Analysis), presentation, and calculate of physics.

\section{Physics Problem Solving}

Problem-solving skills in science teaching and learning is an objective of science learning that is expected to be acquired by students so that they can apply scientific knowledge to the real world meaningfully $[\mathrm{I} 2, \mathrm{I} 3]$. Problem-solving involves various metacognitive strategies to enable students to understand how they think and explore the various methods to solve problems in science $[13,14]$. The ability of problem solving physics able to analyze physical phenomena both real and abstract. students are trained to think of solving physics problems that exist in everyday life.
The Effect of the Microsoft Excel Based Interactive Learning Media...

\section{Method}

This research is the quasi-experiment using post test only for control group design. The subjects were students in Junior High School in Yogyakarta. The number of respondents was 28 students for treatment class and 28 students for the control class.

The dependent variables applied in this study was physics problem solving. The independent variable is learning media in which the control group applied powerpoint, while the trearment group applied multimedia based Microsoft Excel.

The physics problem solving instrumen is evaluation questions with multiple choice and essay. The number of multiple choice are 10 questions and the number of essay are 5 questions. Test results of this evaluation given before (pre test) and after (posttest) of learning, prior to model use the test is first conducted trials to know the level of validity, reliability, problem difficulty level, and differentiator of test.

Test the difference in mean treatment class and control class used t-test with SPSS I6.0 with a margin of error (alpha) of 5\%. As for knowing improvement of the physics problem solving of treatment class and control class is calculated by using gain score normalized as shown in table I.

Table I. The category of gain score

\begin{tabular}{cc}
\hline Range & Category \\
\hline $\mathrm{g}>0,7$ & High \\
$0,3<\mathrm{g} \leq 0,7$ & Medium \\
$\mathrm{g} \leq 0,3$ & Low \\
\hline
\end{tabular}

\section{Result and Discussion}

Based on the results of this research, obtained the results of Pre-test, Post-test and Gain of treatment class and control class as in table 2.

Table 2. the results of Pre-test, Post-test and Gain

\begin{tabular}{lrrrrrr}
\hline \multirow{2}{*}{ Nilai } & \multicolumn{3}{c}{ Treatment Class } & \multicolumn{3}{c}{ Control Class } \\
\cline { 2 - 7 } & $\begin{array}{l}\text { Pre- } \\
\text { test }\end{array}$ & \multicolumn{1}{c}{$\begin{array}{l}\text { Post- } \\
\text { test }\end{array}$} & Gain & \multicolumn{1}{c}{$\begin{array}{l}\text { Pre- } \\
\text { test }\end{array}$} & $\begin{array}{l}\text { Post- } \\
\text { test }\end{array}$ & Gain \\
\hline Maximum & 70 & 86 & 0,77 & 64 & 76 & 0,63 \\
Minimum & 50 & 72 & & 42 & 60 & \\
Average & 61,36 & 80,26 & 54,50 & 68 & \\
Deviation & & & & & & \\
Standard & 4,9 & 3,5 & & 5,4 & 4,4 & \\
\hline
\end{tabular}

Based on table 2, the average value is shown physics problem solving before and after the process learning has improved from results pre-test and post-test of treatment 
class or control class. Increased yield student learning after science-physics learning because of the different treatments inside the learning process (learning media) is in the treatment class used a learning media based Microsoft Excel while in the control class use powerpoint. Improved of physics problem solving in treatment class and control class can seen from acquisition of gain and value categorization of gain in table 2 . The students average value of gain in

Table 3. The result of t-test analysis with SPSS I6.00

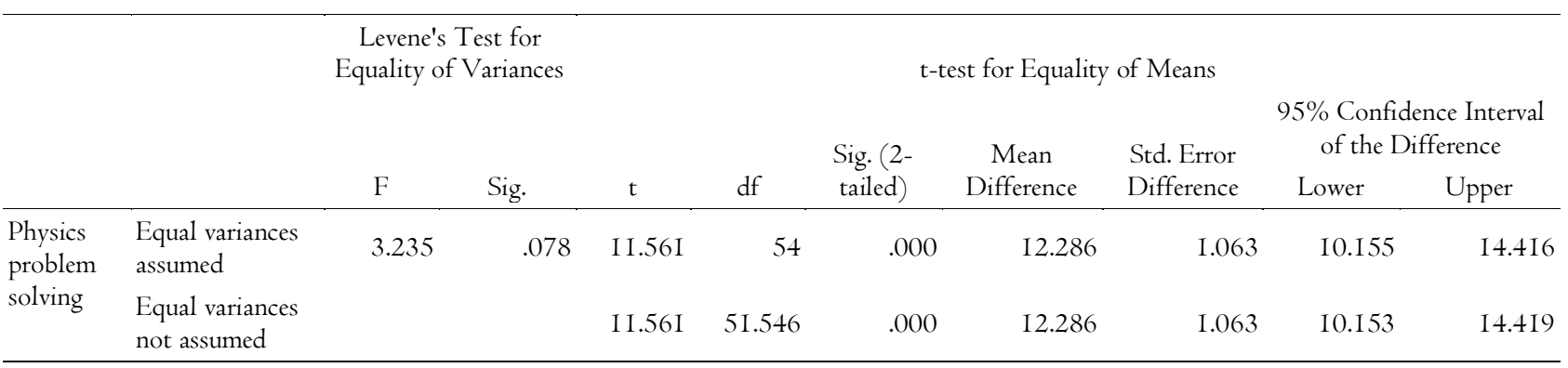

From Table 3 above it can be seen that the physics problem solving between the control group and treatment group were significantly different at the level of error of 5\% or $95 \%$ level of confidence, with sig $0.000(<0.05)$. Hence, it can be said that in the physics problem solving, the students who follow the learning media based Microsoft Excel reached the higher score than students who follow learning media with powerpoint.

Based on the data analysis seen that by using learning media based Microsoft Excel can provide differences in physics problem solving of Science-Physics students compared with using the learning media with Powerpoint. In this research, physics learning by Microsoft Excel shown the students very fun and can improve learning motivation. learning media based 'given to students in the form of learning media whose contents are material, physics animation, physics experimental video, physics phenomena analysis, practice questions and evaluation,

Media is one of the alternatives or learning methods that can make students active. In science education, interaction between objects and students are necessary. If it is not possible, the teacher should be able to make a modification, it could be a model of real objector visualization through other media [I5]. Basic skills of science is an education that not only prioritize the achievement of goals, but the learning process that is directed at the development of students' potential as a whole [I6].

Learning media based Microsoft Excel can improve students' learning skill in learning. Proven students are able treatment class is 0,77 (high category of $77 \%$ ) while the average gain of student learning outcomes in class control that is equal to 0,63 (medium category by $63 \%$ ).

To know the difference in average results the students learn of treatment class with the students of control class using t test, which first used the test data normality or test of data homogeneity, can be viewed in table 3 . to process data using Microsoft Excel itself [17]. In the physics learning of Microsoft Excel is used to analyze the physical phenomena using Microsoft Excel Spreadsheet [18]. It can be interest by the students to improve their skill problem solving. The students can open this media everytime and everywhere. So, the students can study independently.

Problem solving in general and physics problem solving, in particular, encapsulate several intriguing aspects [19]. The identification and exploration of these aspects can offer a multipronged tool to address the issues pertaining to difficulties faced by many students for problem solving. Physics teachers often have the sense that "problem solving is where you learn to actually do physics", where students should learn the process and sense making that exemplifies good physical thinking $[3,20]$. Science teachers recognize that students should be prepared to get information related to technology issues of interest to the general public [2I]. Teachers are able to make the media as interesting as possible so that students are motivated in learning. So with the media can change the cognitive abilities of students in science learning. Multimedia learning occurs when students build mental representations from words and pictures that are presented to them. Science learning by media is that students can learn more deeply from well-designed multimedia messages consisting of words and pictures than from more traditional modes of communication involving words alone [22,23]

Learning by using learning media based on Microsoft Excel this can be used as new learning alternative for 
Astuti \& Bhakti

teachers, because this learning proven can improve problem solving ability especially physics subject. This can be seen from the results of student physics problem solving, where the experimental class obtains the average of indigo better than the control class.

\section{Conclusion}

Based on the analysis, the results of research and discussion can be concluded that the use of learning media based on Microsoft Excel can improve the results of problem solving physics in students. This is in accordance with a normalized gain test that shows an increase in students who were taught using Microsoft Excel based learning media is 0,77 .

\section{References}

[I] Syukri M, Soewarno S, Halim L, Mohtar L E, The Impact Of Engineering Design Process In Teaching And Learning To Enhance Students' Science Problem-Solving Skills, Jurnal Pendidikan IPA Indonesia, vol. 7, no. I, 2018, pp. 66-75.

[2] Hoellwarth, C., Moelter, M. J., \& Knight, R. D, A direct comparison of conceptual learning and problem solving ability in traditional and studio style classrooms, American Journal of Physics, vol 73, no. 5, 2005, pp. 459-462.

[3] Tuminaro, J., \& Redish, E. F, Student Use of Mathematics in the Context of Physics Problem Solving: A cognitive model U, of Maryland preprint, 2005.

[4] Walsh, L. N., Howard, R. G., \& Bowe, B, Phenomenographic study of students' problem solving approaches in physics, Physical Review Special Topics-Physics Education Research, vol. 3, no. 2, 2007, pp. 020108.

[5] Matsuo. K, Barolli. L, Xhafa F, Koyama A \& Durresi A, New Function for stimulating learners' motivation in a web-based elearning system. Journal of Distance Education Technologies, 2008, pp. 34-49.

[6] Sakat.A A, Mohd Zin. M Z, Muhamad. R, Ahmad. A, Ahmad. N A., \& Kamo. M A, Educational technology media method in teaching and learning progress. American Journal of Applied Science, 2012, pp. 874-888.

[7] Astuti, IAD \& Bhakti, YB. Interactive Learning Multimedia Based Microsoft Excel On The Temperature and Heat. Unnes Science Education Journal, vol. 7, no. I, 2018, pp. I-6.

[8] Dagiane. V, Ignatova. N \& Kubilinskiene. S, ICT-based learning personalization affordance in the context of implementation of constructionist learning activities, Informatics in Education - An International Journal, vol. I4, no. I, 2015, pp. 53-67.

[9] Sukarno \& Sutarman D, The Development Of Light Reflection Props As A Physics Learning Media In Vocational High School Number 6 Tanjung Jabung Timur, International Journal of
Volume I, Number I, 2018 The Effect of the Microsoft Excel Based Interactive Learning Media...

Innovation and Scientific Research, vol. I2, no. 2, 2014, pp. 346355.

[10] González,M Á, Martín M E, Llamas C, Martínez Ó, Vegas J, and Hernández C 2017 Teaching and learning physics with smartphones. In Blended Learning: Concepts, Methodologies, Tools, and Applications (pp. 866-885). IGI Global.

[II] Bharathy J B, Importance of Computer Assisted Teaching \& Learning Methods for Chemistry, Science, vol. 3, no.4 , 2015, pp. I I-I6.

[12] Syukri M, Soewarno S, Halim L, Mohtar L E, The Impact Of Engineering Design Process In Teaching And Learning To Enhance Students' Science Problem-Solving Skills, Jurnal Pendidikan IPA Indonesia, vol. 7, no. I, 2018, pp. 66-75.

[13] Lee M K, \& Erdogan I, The effect of science-technology-society teaching on students' attitudes toward science and certain aspects of creativity. International Journal of Science Education, vol. 29, no. 2, 2007, pp. 13I5-I327.

[I4] Halim A, Yusrizal Y, Susanna S, \& Tarmizi, T, An analysis of students' skill in applying the problem solving strategy to the physics problem settlement in facing AEC as global competition. Jurnal Pendidikan IPA Indonesia, vol. 5, no. I, 2016, pp. I-5.

[15] Rahman MJA, Ismail. M A \& Nasir. M, Development and evaluation of the effectiveness of computer-assisted physics instruction. International Education Studies, vol. 7, no. I3, 20I4, pp. I4.

[I6] Bhakti, YB \& Astuti, IAD. The Influence Process of Science Skill and Motivation Learning with Creativity Learn. Journal of Education and Learning, vol. I2, no. I, 2018, pp. 30-35.

[17] Bruce. W C \& Meehan. A M, Microsoft Excel ${ }^{\mathrm{TM}}$ as a tool for teaching basic statistics. Teaching of Psychology, vol. 28, no. 4, pp. 295-298.

[18] Brown. A M, A step-by-step guide to non-linear regression analysis of experimental data using a Microsoft Excel spreadsheet, Computer methods and programs in biomedicine, vol. 65, no. 3, pp. I9I-200.

[19] Hegde B \& Meera B N, How do they solve it? An insight into the learner's approach to the mechanism of physics problem solving, Physical Review Special Topics - Physics Education Research, vol. 8, no. I, 20I2, pp. 01010.

[20] Yang, Ya-Ting Carolyn, Building virtual cities, inspiring intelligent citizens: Digital games for developing students' problem solving and learning motivation, Computers \& Education, vol. 59, no. 2, 2012, pp. 365-377.

[2I] Firdaus T, Setiawan W, \& Hamidah, I, The Kinematic Learning Model using Video and Interfaces Analysis, In Journal of Physics: Conference Series, vol. 895, no. I, 2017, pp. 012108. IOP Publishing.

[22] Chandler P D, Middle years students' experience with new media, Australian Journal of Education, vol. 57, no. 3, 2013, pp. 256269.

[23] Mayer R E, The promise of multimedia learning: using the same instructional design methods across different media, Learning and instruction, vol. I3, no. 2, 2003, pp. I25-I39. 